Research article

\title{
Biostratigraphy analysis of Barbatos-1 exploration well in Tomori Block, Banggai Basin, east arm of Sulawesi
}

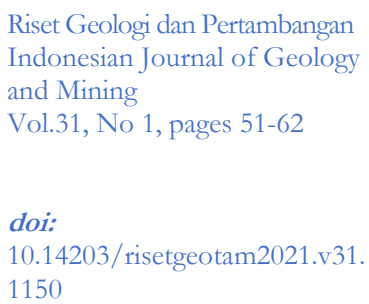

(C)2021 Pusat Penelitian Geoteknologi - Lembaga Ilmu Pengetahuan Indonesia

This is an open access article under the CC BY-NC-ND license

(http://creativecommons.org/1 icenses/by-nc-nd/4.0/).

\author{
Anis Kurniasih ${ }^{*}$, Ennur Kusumawijaya ${ }^{2}$, Ferdy $^{2}$, Fahrudin1, \\ Reddy Setyawan ${ }^{1}$ \\ ${ }^{1}$ Geological Engineering, Diponegoro University (UNDIP), Semarang \\ ${ }_{2}^{2}$ Joint Operating Body (JOB) Pertamina-Medco E\&P Tomori Sulawesi
}

\begin{abstract}
A biostratigraphic analysis was carried out on 60 samples taken from the Barbatos-1 Well, located within the Tomori Block, Banggai Tertiary Basin, East Arm of Sulawesi. The Barbatos-1 well was selected for this study because it is composed of rock sequences which are the main reservoir in the Tomori Block. Biostratigraphic analysis was conducted to determine the relative age and depositional environment of the sample. The age of the sample is determined based on the interval zone. The depositional environment is estimated based on the ratio of plankton (P/B ratio) and fossil facies. The results revealed that the rock formations studied were deposited in the Miocene to Holocene age. The lowest layer is the Orbulina bilobataZone which was deposited at N10 - N12 (lower Middle Miocene) in the bathyal environment. The layer above is a biozonation of Globorotalia menardii, deposited at N12 - N14 (upper Middle Miocene) in a neritic environment. The next layer is the biozonation of Sphaeroidinella subdehiscens - Globigerina praebulloides which was deposited at N14 - N17 (Middle Miocene - Late Miocene) in the bathyal environment. The topmost layer is the biozonation of Orbulina universa - Globigerinoides immaturus which was deposited at N17 N23 or Pliocene - Holocene in the bathyal environment. In the top two layers, there are fossil fragments that come from older rock layers (Early Tertiary).
\end{abstract}

\section{INTRODUCTION}

Biostratigraphic analysis is one of the important stages in hydrocarbon exploration. This analysis aims to reconstruct the geological history based on the determination of the relative age of rocks and their depositional environment. Biostratigraphic analysis complemented by analysis of faunal abundance, diversity, and composition can be applied to identify stratigraphic sequences (Maryunani, 1998). Sequence boundaries were identified based on the presence of shatter zones which could be related to the erosion process of the older rocks.

Ferdian et al. (2010) re-evaluated the geological structure in the northern part of the Banggai-Sula Basin and explained that the Miocene carbonate rock sequence in this area has the potential as a hydrocarbon reservoir. The presence of a thick layer of shale that covers the carbonate rock layer may be the source rock as well as the cap rock layer, supporting the possibility of the formation of 
the hydrocarbon reservoir. The presence of widespread faults and folds may also support the formation of several petroleum systems in this area.

Research on biostratigraphy in the Banggai Basin has been carried out by several researchers, including Putri et al. (2018), Fakhruddin and Kurniadi (2019), Prabawa et al. (2020), and Yoga et al. (2020). Putri et al. (2018) stated that the Mantawa Formation and the Minahaki Formation were deposited at the Late Miocene-Early Pliocene age in the Restricted Interior Platform depositional facies. Meanwhile, Fakhruddin and Kurniadi (2019) used outcrop samples from the Tertiary carbonate rock group on the Poh - Pagimana stratigraphic transect. The analysis of foraminifera shows, the relative age of these rock groups is Early Miocene - Pliocene, and the depositional environment is from the middle shelf to the upper bathyal. Prabawa et al. (2020) examined the characteristics of carbonate reservoir rocks in the Banggai Basin and obtained the relative age of the Middle Eocene-Early Pliocene. Yoga et al. (2020) focused their research on carbonate rocks of the Mantawa Formation and obtained the relative age of the Late Miocene - Early Pliocene.

These previous studies focused more on Tertiary carbonate rock formations ranging from the Tomori Formation to the Minahaki Formation. The Tomori Formation to the Minahaki Formation is equivalent to the Salodic Group carbonate rocks formed before the Banggai-Sula microcontinent collision with the East Arm of Sulawesi (Hasanusi et al., 2015; Panggabean and Surono, 2011). Meanwhile, this study, apart from analyzing the carbonate rocks of the Tomori Formation to the Minahaki Formation, also analyzed rock samples from the Kintom Formation which were formed after the collision. It aims to better understand the history of rock deposition at the studied area in the time span before and after the collision based on biostratigraphic analysis.

\section{GEOLOGICAL SETTING}

The study area is located in the Tiaka Oil Field, Tomori Block, administratively included in the Banggai Regency, Central Sulawesi Province (Figure 1). The Tomori Block is physiographically situated in the Banggai Tertiary Basin in the Eastern Arm of Sulawesi (Hasanusi et al., 2015). Geologically, this block is composed of a Miocene collision complex produced by the collision of the Banggai-Sula microcontinent with the Sulawesi Tertiary non-volcanic arc (Hasanusi et al., 2015). The Banggai-Sula microcontinent is interpreted as a fragment of the Australia-New Guinea Plate moving relative to the west toward Sulawesi. This plate interaction led to the formation of Central Sulawesi (Hasanusi et al., 2015).

The main reservoir in the Banggai Basin is the Early to Middle Miocene carbonate rock formations, namely the Tomori Formation and the Minahaki Formation. The two formations are separated by a unit of clastic sedimentary rock of Matindok Formation, which was deposited in a deep-sea environment. The Mantawa Formation and the Kintom Formation, which are grouped into the Pliocene - Pleistocene Sulawesi Molasses Group, were deposited above the Minahaki Formation (Hasanusi et al., 2015). Lithostratigraphy of the Barbatos-1 Well is composed of these rock formations (Final well report Barbatos-1, 2014). The Tomori Formation consists of fine-grained clastic limestone. Large and small foraminifera are present as bioclasts. The Matindok Formation consists of claystone with carbonate fragments of foraminifera and algae and sandstone interbeds. The Minahaki Formation is represented by clastic limestone, which shows increased allochems and decreased carbonate mud matrix toward the top. The Mantawa Formation consists of limestone with bioclasts of small and large foraminifera. Dolomite is present in the lower part of the formation. The Kintom Formation consists of clastic sediment layers in which lithic and polycrystalline quartz are present as the main components. 


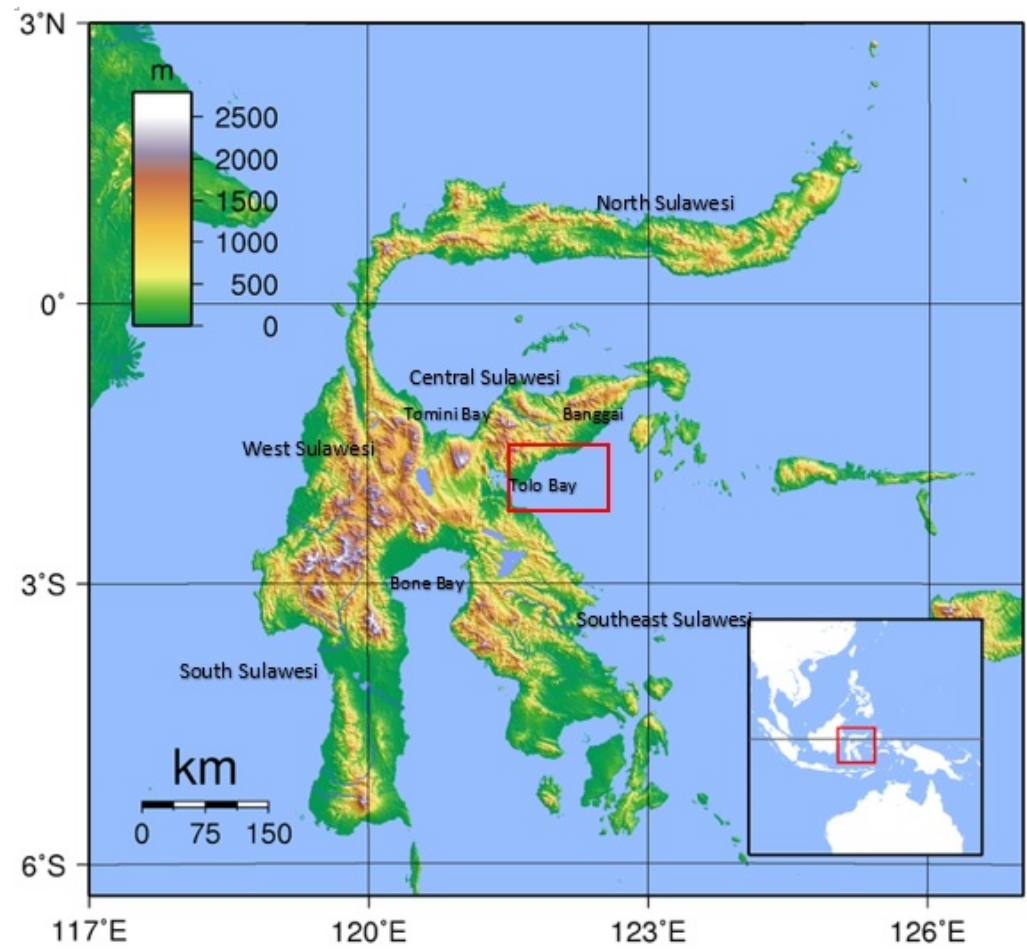

Figure 1. Map of Sulawesi and the research location (red box) located in the waters of Tolo Bay, Central Sulawesi.

\section{METHOD}

Biostratigraphic analysis was carried out on 60 samples taken from the drilling of the Barbatos-1 exploration well, Tiaka oil field, Banggai Basin. All samples were taken at a depth range of $4030-$ 9900 feet without any specific interval. Cutting samples are described based on grain size, hardness, and composition. Sand to clay grained samples with a carbonate composition that easily crushed were selected for biostratigraphic analysis.

Small foraminiferal fossils were separated from the sample following the standard procedure by Armstrong and Brasier (2005). The separation of small foraminifera fossils was carried out using an Olympus SZ61 series zoom stereo microscope. All fossils found were separated from the sample. Foraminifera fossil identification refers to Postuma (1971), Morkhoven et al. (1986), and Loebligh and Tappan (1988). The identification results are presented in a frequency table. The frequency of each type of foraminifera in each sample grouped its abundance qualitatively according to Natsir et al. (2017).

The age of the sample was determined based on the assemblage of planktonic foraminifera. The depositional environment was determined based on the assemblage of benthic foraminifera. The biozonation was carried out using the Interval Zone, utilizing the stratigraphic interval of the first appearance of two taxons (Komisi Sandi Stratigrafi Indonesia, 1996). The age of each taxon refers to Blow (1969). The depositional environment was determined based on the plankton-benthos ratio (P/B ratio) following Gibson (1989), and the bathymetric zone (Table 1) was determined following Murray (1976). Determination of benthic foraminifera habitat refers to Hollbourn et al. (2013). 


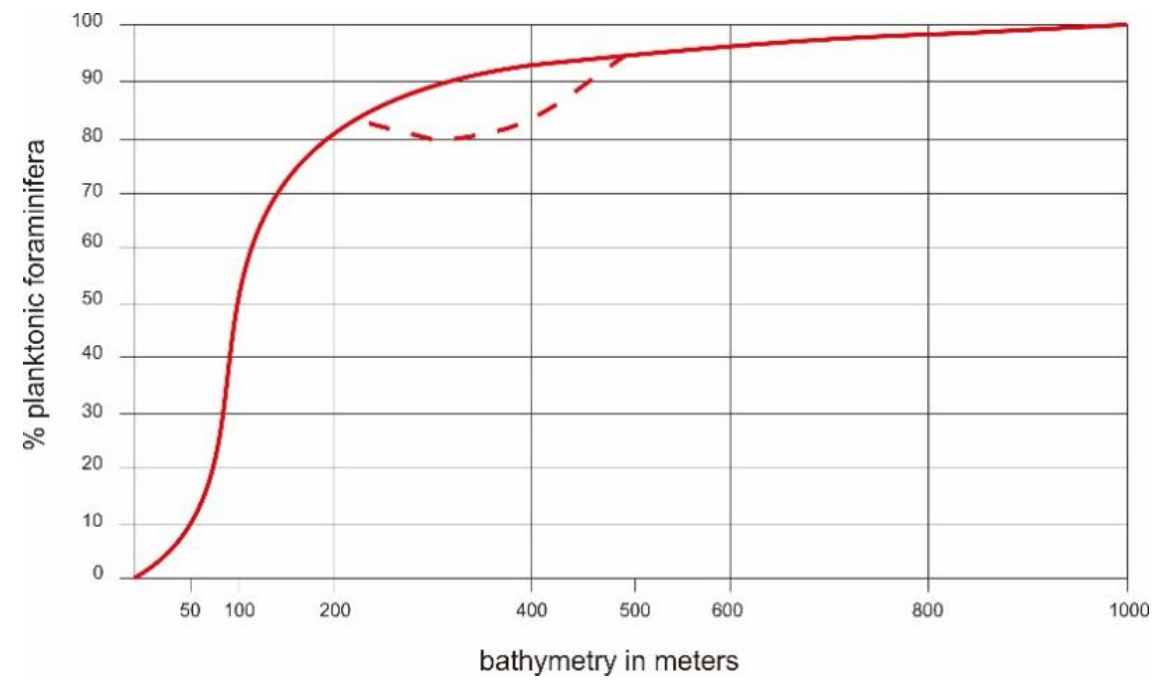

Figure 2. The relationship between the frequency of presence of planktonic foraminifera and depth or bathymetry (Gibson, 1989). The dotted line represents the relationship between the two at the continental margin.

Table 1. The relationship between the frequency of the presence of planktonic foraminifera and depth (Murray, 1976).

\begin{tabular}{cl}
\hline $\begin{array}{c}\text { Frequency of Planktonic } \\
\text { Foraminifera }\end{array}$ & $\begin{array}{c}\text { Bathymetry } \\
\text { Zone }\end{array}$ \\
\hline$<20 \%$ & Inner shelf \\
$10-60 \%$ & Middle shelf \\
$40-70 \%$ & Outer shelf \\
$>70 \%$ & Upper slope \\
$\pm 90 \%$ & Lower slope \\
\hline
\end{tabular}

\section{RESULT}

\section{Foraminifera Distribution}

Planktonic and benthic foraminifera were present in 55 of the 60 samples analyzed with varying abundances. Five samples did not contain foraminifera, consisting of samples at depths of 5440, 8370, 8500, 8580, and 9560 feet. The abundance of foraminifera in all samples is shown in Figure 3. The samples at depth intervals of 6820 - 7600, 8550, $9300-9400$, and 9900 feet contain foraminifera with abundant categories. Samples at depth intervals of $4030-5020,7210,8000$, and 8520 feet contain foraminifera with moderate category. Other samples contain foraminifera with rare and very rare categories.

Thirteen species of planktonic and twenty-four benthic foraminifera species were identified in all samples. The species with abundant frequency were Orbulina universa, Orbulina bilobata, Globigerinoides immaturus, Sphaeroidinella subdehiscens, Elphidium macellum, Bathysiphon sp., and Melonis barleeanum. 


\section{Age of Rocks}

Biozonation using the Interval Zone resulted in four biostratigraphic zones in the Barbatos-1 Well, i.e., the Globorotalia menardii-Orbulina bilobata Zone, the Globorotalia menardii-Sphaerodinella subdehiscens Zone, the Sphaerodinella subdehiscens-Globigerina praebulloides Zone, and the Globigerina praebulloidesOrbulinauniversa- Globigerinoides immaturus Zone (Figure 3).

1) Globorotalia menardii-Orbulina bilobata Zone (N10 - N12)

This zone is at a depth interval of 9800 - 9900 feet. The upper boundary is indicated by the first occurrence datum (FOD) of Globorotalia menardii at a depth of 9800 feet and the presence of Orbulina bilobata, Globorotalia bulloides, and Globorotalia tumida. According to Blow's age biozonation (1969), Orbulina bilobata has an age range of N10 - N23, and Globorotalia menardii has an age range of $\mathrm{N} 12$ - N23. Thus, the age of this zone ranges from N10 to N12 or equivalent to the Middle Miocene.

2) Globorotalia menardii-Sphaerodinella subdehiscens Zone (N12 - N14)

This zone is at a depth interval of 7420 - 9800 feet. The lower boundary of this zone is characterized by the first occurrence (FOD) of Globorotalia menardi at a depth of 9800 feet and the upper boundary by the first occurrence datum (FOD) of Sphaeroidinella subdehiscens at a depth of 7330 feet. Globorotalia obesa are also present in this zone. Referring to Blow's age biozonation (1969), Sphaeroidinella subdehiscens has an age range of N14 - N19. Thus, the age of this zone is in the range of N12 - N14 or equivalent to the Middle Miocene.

3) Sphaerodinella subdehiscens-Globigerina praebulloides Zone (N14 - N17).

This zone is at a depth interval of $6160-7330$ feet. The lower boundary is characterized by the first occurrence datum (FOD) of Sphaeroidinella subdehiscens and is supported by the presence of Globigerinoides immaturus, Orbulina universa, and Globorotalia opima at a depth of 7330 feet. The upper boundary is characterized by the last occurrence datum (LOD) of Globigerina praebulloides at a depth of 6010. Referring to Blow's age biozonation (1969), Globigerina praebulloides has an age range of N1-N17. Thus, the age of this zone ranges from N14 - N17 or equivalent to the Middle Miocene - Late Miocene.

4) Globigerina praebulloides-Orbulinauniversa-Globigerinoides immaturus Zone (N17 - N23)

This zone is at a depth interval of 4030 - 6010 feet. The lower boundary is characterized by the last appearance datum (LOD) of Globigerina praebulloides at a depth of $6010 \mathrm{ft}$ and is supported by the presence of Orbulina universa and Globigerinoides immaturus. Referring to Blow's age biozonation (1969), Orbulina universa has an age range of N10 - N23 and Globigerinoides immaturus N5 - N23. Thus, the age of this zone ranges from N17 - N23 or equivalent to the Late Miocene - Holocene.

Reworked fossils were found in several samples, consisting of Globorotalia opima (samples 5020, 6010, 6730, 6820, 7150, 7180, 7240, 7520, and $7600 \mathrm{ft}$ ), Globigerinoides diminutus (samples $4030 \mathrm{ft}$ ), and Globigerinoides subquadratus (samples 4030, 5020, 6370 and 7420 feet). Referring to Blow's age biozonation (1969), the three species have an age range of N2 - N4, N7-N8, and N5-N12, respectively. The presence of these three species with other, younger types indicates that all three are reworked fossils. 


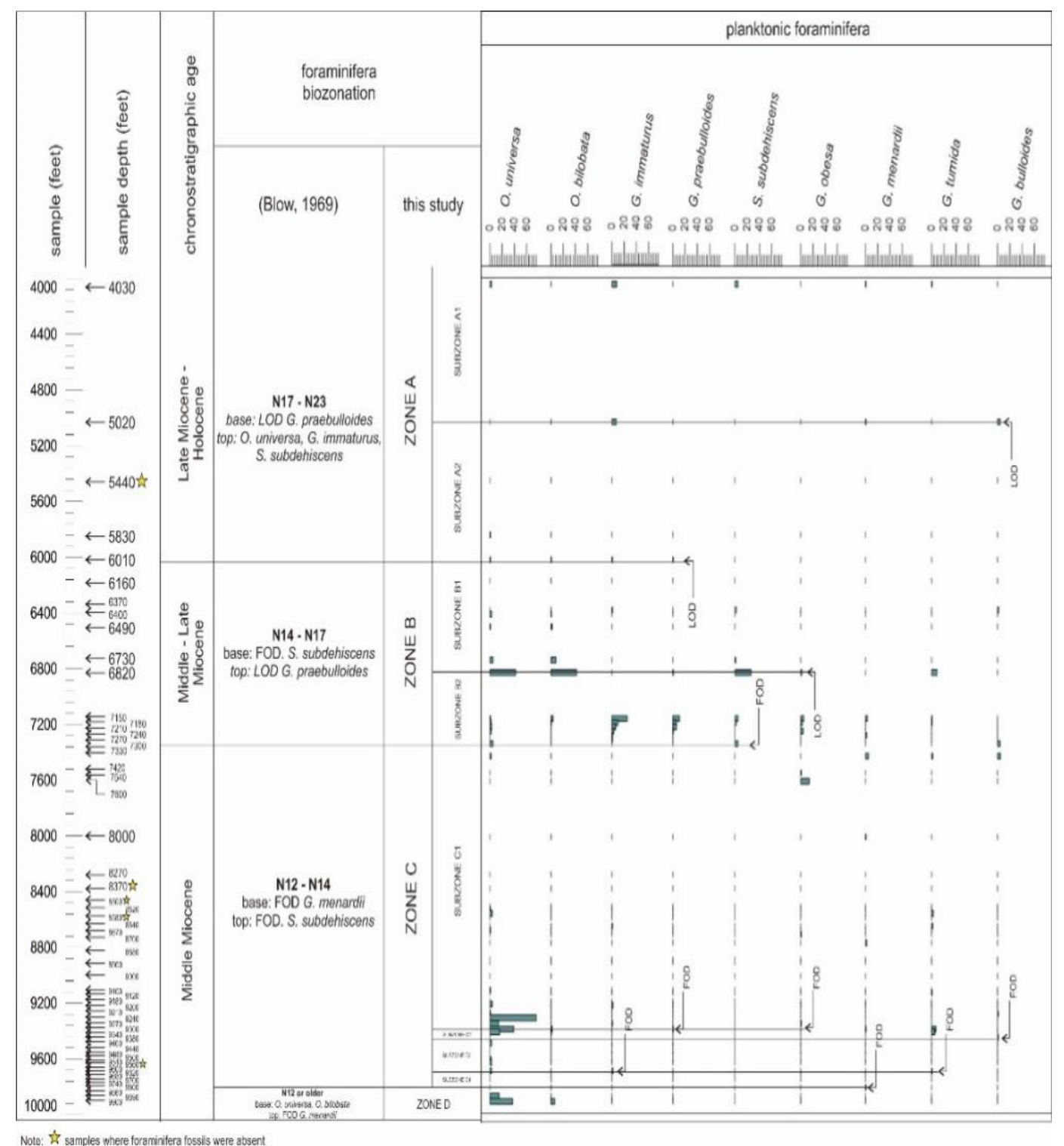

Figure 3. Distribution of foraminifera fossils and the results of foraminifera biozonation analysis at the Barbatos-1 Well (continued in the next page).

\section{Depositional Environment}

The depth zone of the depositional environment of the samples in the Barbatos- 1 Well was interpreted based on the calculation of the $\mathrm{P} / \mathrm{B}$ ratio and the presence of facies fossils. The interpretation results are shown in Figure 4.

Samples in the depth range of $9860-9900$ feet show a P/B ratio of $58-75 \%$. Referring to the Gibson classification (1989), this value indicates the depositional environment is in the range of 100 - 200 meters. According to the classification of Murray (1979), this value indicates the depositional environment is in the upper slope zone. The presence of Melonis pompiloides which generally lives in the outer neritic zone to the middle bathyal, indicates the depositional environment is in the upper bathyal zone. 


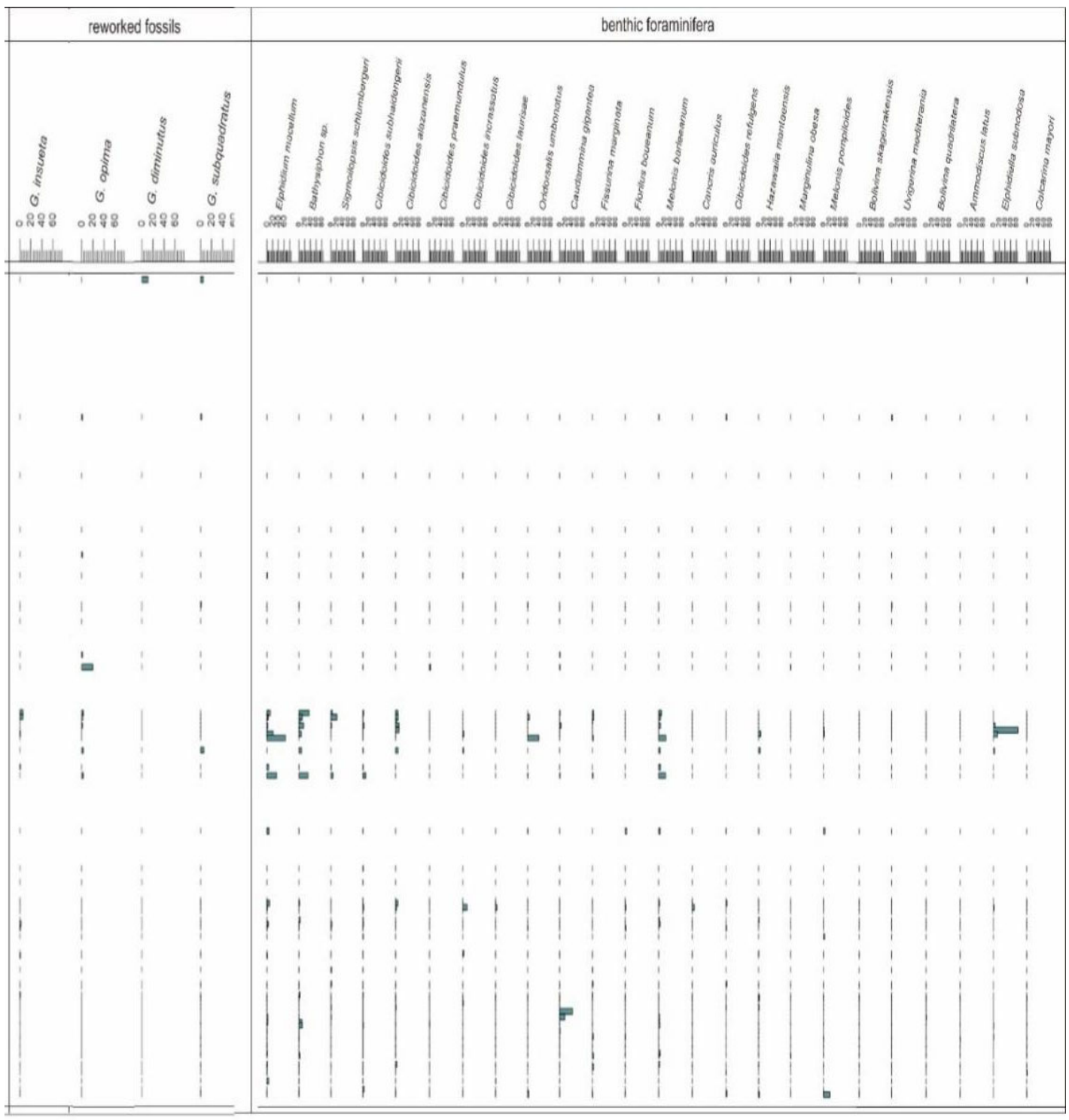

Figure 3. Distribution of foraminifera fossils and the results of foraminifera biozonation analysis at the Barbatos-1 Well (continued from previous page).

Samples in the depth range of $9440-9800$ have a P/B ratio of $0-35 \%$. Referring to the Gibson classification (1989), this value indicates the depositional environment is in the depth range of 50 - 100 meters. According to Murray's (1979) classification, this value indicates that the depositional environment is in the middle shelf zone. The presence of Melonis barleeanum indicates that the depositional environment is in the neritic to bathyal zone. Meanwhile, the presence of Fissurina marginate indicates a neritic zone. Thus, the depositional environment of these samples is in the neritic zone.

Samples in the 9120 - 9380 depth range have a P/B ratio of $30-75 \%$. Referring to the Gibson classification (1989), this value indicates the depositional environment is in the range of $100-200$ meters. According to Murray's (1979) classification, this value indicates the outer shelf - upper 
slope zone. The presence of Caudammina gigantea indicates the bathyal to abyssal zone. Thus, the depositional environment of these samples is in the bathyal zone.

Samples in the depth range of 7240 - 9100 feet have a P/B ratio of $0-33 \%$. Referring to the Gibson classification (1989), this value indicates the depositional environment is at a depth of 50-100 meters. According to Murray's (1979) classification, this value indicates the middle shelf zone. The abundance of benthic taxa in these samples, including Melonis barleeanum (neritic-bathyal zone), Cibicidoides subhaidingerii (neritic-lower bathyal zone), and Sigmoilopsis schlumbergeri (neriticabyssal zone), indicated that the depositional environment was in the neritic zone.

Samples in the depth range of $4030-7210$ feet have a P/B ratio of $50-100 \%$. Referring to the Gibson classification (1989), this value indicates a depth of 200 - 400 meters. According to the classification of Murray (1979), this value indicates the upper slope - lower slope zone. The presence of Uvigerina mediterranean (lower neritic - upper bathyal), Elphidium macellum (neritic bathyal), and Cibicidoides refulgens (middle neritic - bathyal), the depositional environment of these samples are in the bathyal zone.

\section{DISCUSSION}

Biostratigraphic analysis of the Barbatos-1 Well (Figure 5) shows that the history of deposition in the study area begins in the Middle Miocene. During this period, the lower Tomori Formation was deposited in different depositional environments, from upper bathyal to neritic. Changes in the depositional environment occurred in parallel with the deposition of only 40 feet of sediment. As a consequence, a reduction in accommodation space of more than 200 feet is required. This reduction may be compensated by the process of tectonic uplift.

The depositional environment deepened when the upper Tomori Formation and Matindok Formation were deposited. The Matindok Formation is characterized by a lithology of claystone with a mixture of carbonate fragments and sandstone inserts. This formation was deposited during the Middle Miocene in the upper bathyal environment. These environmental changes are consistent with the build-up of sediment over 300 feet thick. This implies the presence of an overall accommodation space of more than 600 feet. This large accommodation space indicates a significant tectonic subsidence.

When the Minahaki and Mantawa Formation were deposited in the middle and upper Middle Miocene, the depositional environment had become shallower by more than 260 feet. These changes may be entirely the result of sediment build-up and/or accompanied by minor tectonic uplift. The Minahaki Formation is characterized by limestone and dolomitic limestones, while the Mantawa Formation is composed of reef limestones. The deposition of these formations indicates the presence of a shallower depositional environment, thus supporting the growth of reef ecosystems. The thickness of these two formations, which reaches more than 1800 feet, indicates the increase in accommodation space was taking place along with the deposition process. The increase in accommodation space was presumably due to tectonic subsidence.

The tectonic subsidence phase still persisted until the Kintom Formation was deposited in the Late Miocene-Holocene. Changes in the depositional environment from the middle neritic environment to the bathyal environment presumably took place more rapidly, thus hampering the persistence of the carbonate ecosystem. 
The biostratigraphic analysis shows that in line with the deposition of the Tomori Formation, Matindok Formation, Minahaki Formation, and Mantawa Formation (Salodic Group) in the Middle Miocene, shallowing and deepening of the depositional environment occurred repeatedly. Shallowing of the depositional environment can be triggered by sediment build-

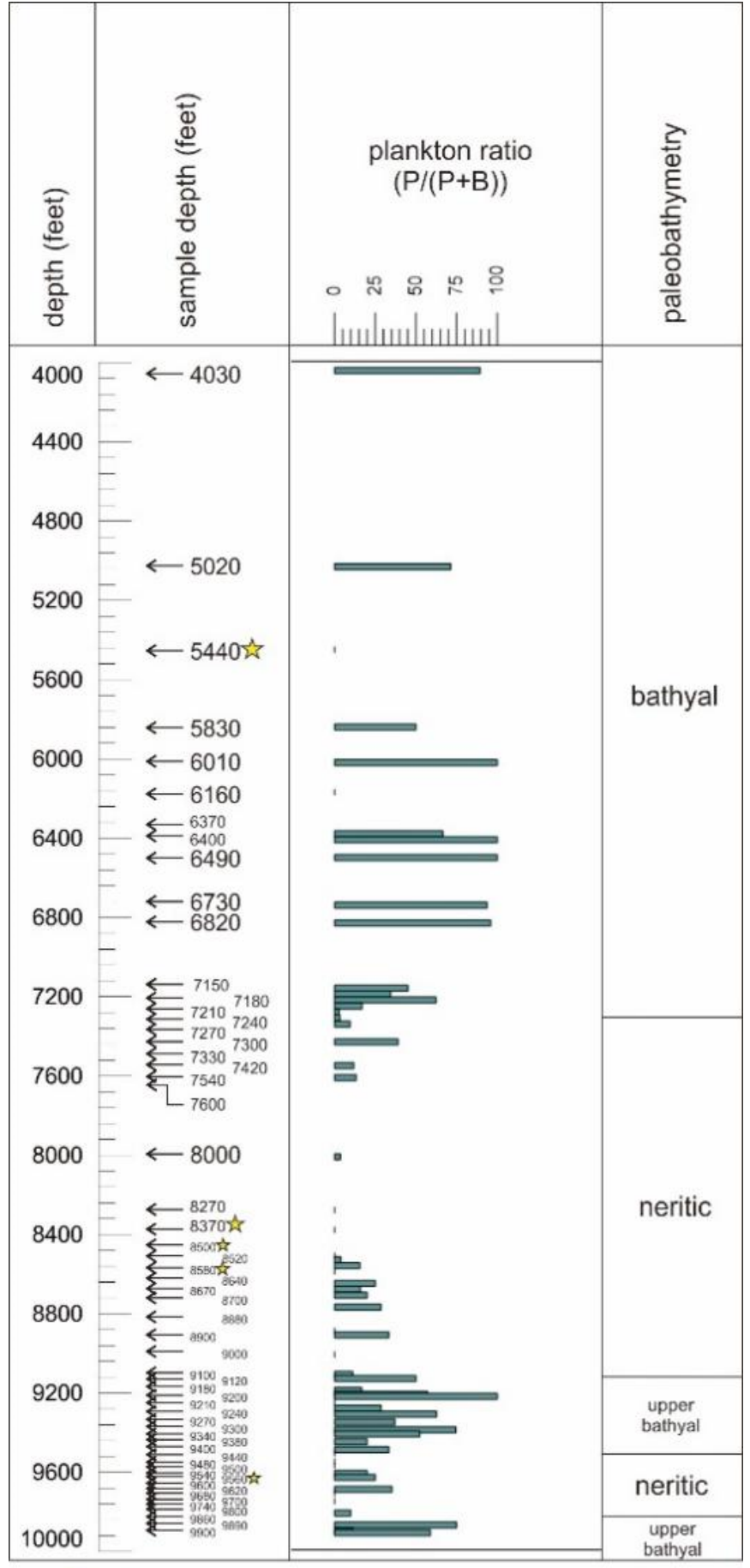

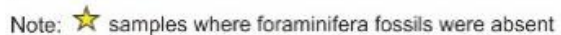

Figure 4. $\mathrm{P} / \mathrm{B}$ ratio and paleobatymetric interpretation of the Barbatos-1 Well. 


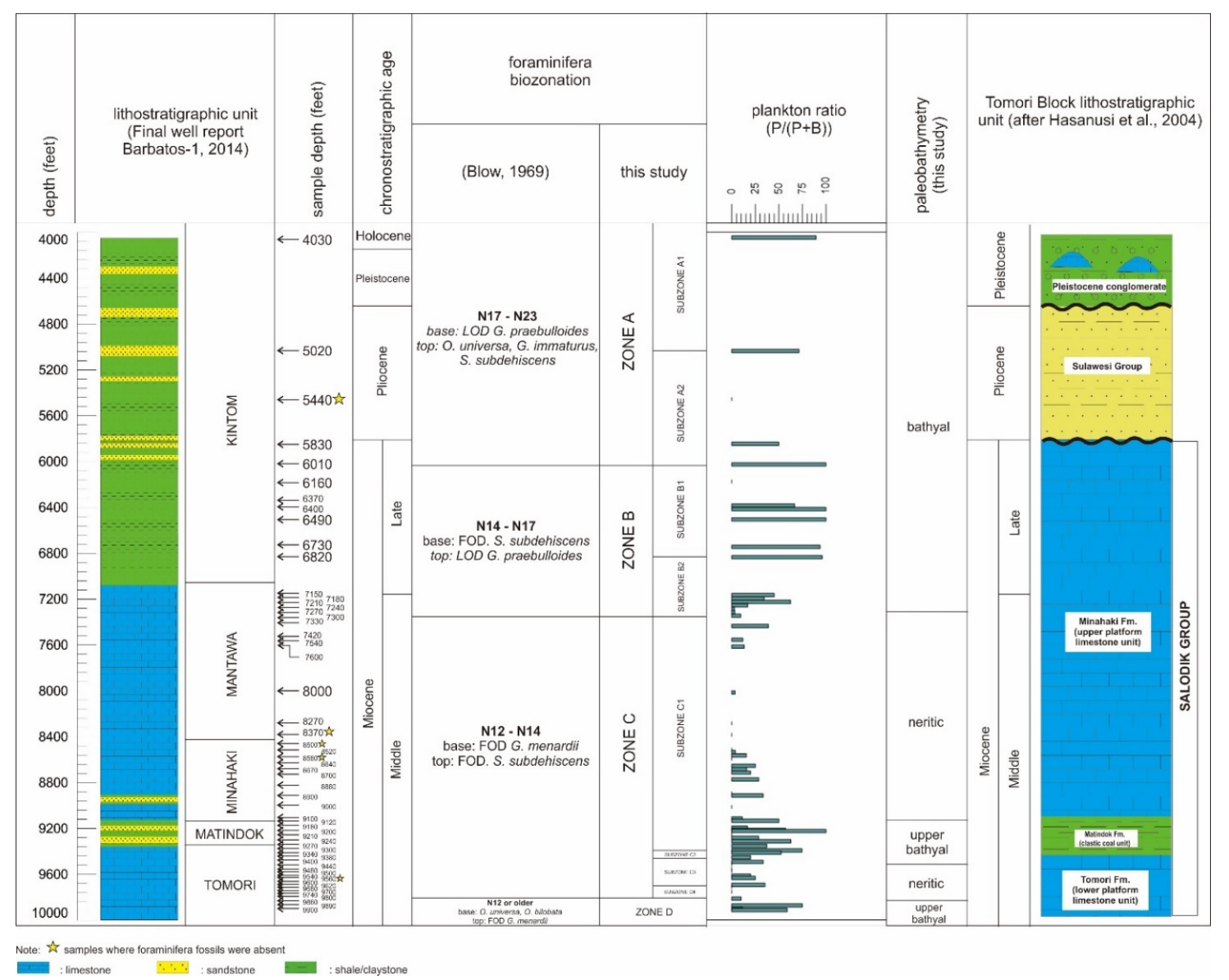

Figure 5. Biostratigraphy of small foraminifera in the Barbatos-1 Well and their comparison with lithostratigraphic units in the Tomori Block (Hasanusi et al., 2004).

up, uplift of the basin floor due to tectonic movements, or the interaction of these two processes. The uplift of the basin floor may have occurred considering the tectonic setting of the Banggai Basin lies within a complex tectonic system of the Banggai-Sula microcontinent collision with the Sulawesi Tertiary (Hasanusi et al., 2015). The collision process has led to the formation of a thrust fault system at the edge of the basin, which has facilitated shallowing processes of the basin. Meanwhile, the process of basin deepening is presumably related to extensional tectonic phases.

The deposition of these formations may be related to the collision of the Banggai-Sula microcontinent with the eastern arm of Sulawesi. The biostratigraphic analysis shows that there is a possibility of minor tectonic extension during the collision phase. However, the extension tectonic phase just started intensively along with the deposition of the Minahaki Formation, Mantawa Formation, and Kintom Formation. The phase of tectonic subsidence is described by Panggabean and Surono (2011) as subsidence due to extension in the middle of the basin after the collision of the Banggai-Sula microcontinent with the eastern arm of Sulawesi; described by Hasanusi et al. (2004) as Sulawesi molasses deposits. 
Moreover, the biostratigraphic analysis also shows the presence of reworked fossils in the Kintom Formation, i.e., Globorotalia opima, Globigerinoides diminitus, Globigerinatella insueta, and Globigerinoides subquadratus. These fossils are early Miocene age marker, and are present in Late Miocene rocks. The presence of reworked fossils can be caused by erosion processes of older rock layers that have been uplifted and deposited in younger sediments (Simmons, 2019). Thus, we interpret that the Late pre-Miocene collision in the eastern arm of Sulawesi has resulted in older rocks being uplifted and exposed. During post-collision, these rocks were eroded and redeposited in the deepening depositional basin due to extension tectonic processes.

\section{CONCLUSIONS}

Foraminifera biostratigraphic analysis of cutting samples from exploration well Barbatos-01 yielded the following conclusions: 1 . Rock formations from this well were deposited during the Middle Miocene to Holocene. 2. The samples from the well are divided into four foraminifera biozonation, i.e., the Globorotalia menardii-Orbulina bilobata Zone, the Globorotalia menardiiSphaerodinella subdehiscens Zone, the Sphaerodinella subdehiscens-Globigerina praebulloides Zone, and the Globigerina praebulloides-Orbulina universa-Globigerinoides immaturus Zone; 3. Foraminifera assemblages show that shallowing and deepening of the basin has occurred repeatedly due to collisional tectonic processes in the eastern Sulawesi arm. The collision tectonic phase occurred at least from the Middle Miocene to the upper part of the Middle Miocene. Some minor tectonic extensions, however, occurred in this phase. Subsequently, the extension tectonic phase occurred until the Holocene.

\section{ACKNOWLEDGEMENTS}

The authors would like to thank the energy resource research team, Department of Geological Engineering, Diponegoro University, and LPPM, Diponegoro University, for their cooperation and support in completing this research. The author also expresses deep appreciation to the micropaleontology team of the Sediment, Oil and Gas Laboratory, Geological Engineering Department, Diponegoro University for providing research facilities and assisting in the preparation and identification of fossil foraminifera. The authors also thank the anonymous reviewers who have provided input and improvements for this manuscript.

\section{REFERENCES}

Armstrong, H.A. dan Brasier, M.D., 2005. Microfossils 2nd Edition, Blackwell Publishing, Australia. 273 - 277.

Blow, W.H., 1969. Late Middle Eocene to Recent planktonic foraminiferal biostratigraphy, 1st International Conference of Planktonic Microfossils Proceedings. 199 - 421.

Fakhruddin, R. dan Kurniadi, D., Age and paleobathymetry of Salodik Group in Poh-Pagimana section, East Arm of Sulawesi based on foraminiferal assemblages, 2019. Journal of Geoscience, Engineering, Environment, and Technology vol. 04 no. $01.30-39$.

Ferdian, F., Hall, R., Watkinson, I., 2010. A structural re-evaluation of The North Banggai-Sula Area, eastern Indonesia, Proceedings Indonesian Petroleum Association 34th Annual Convention and Exhibition.

Final well report Barbatos-1, 2014. JOB Pertamina-Medco Tomori E\&P Sulawesi. Tidak dipublikasikan.

Gibson, T.G., 1989. Planktonic benthonic foraminiferal ratios: modern patterns and Tertiary applicability, Marine Micropaleontology vol. 15 no. 1-2. 29 - 52. 
Hasanusi, D., Abimanyu, R., Artono, E., dan Baasir, A.,2004. Prominent Senoro Gas Field discovery in Central Sulawesi, Proceedings Deepwater and Frontier Exploration in Asia and Australia Symposium.

Hasanusi, D., Sumarianto, J., Wijaya, R., Hendrian, D., 2015. The Tiaka-Tiara fault bend fold structures and its implication to control hydrocarbon entrapment within fracture carbonate reservoir in the Eastern Arm of Sulawesi, Indonesia, Proceedings AAPG/SEG International Conference \& Exhibition 2015.

Holbourn, A., Henderson, A.S., and MacLeod, N., 2013. Atlas of benthic foraminifera. London. Wiley-Blackwell.

Komisi Sandi Stratigrafi Indonesia, 1996. Sandi Stratigrafi Indonesia Edisi 1996 (revisi SSI 1973), Ikatan Ahli Geologi Indonesia. 25 - 27.

Loebligh, A.R., dan Tappan, H.N., 1988. Foraminiferal genera and their classification. New York. Springer.

Maryunani, K.A., 1998. Pola sebaran foraminifera dalam hubungannya dengan stratigrafi sikuen (Studi kasus: Daerah Blora dan sekitarnya/daerah lintang rendah), Proceedings ITB vol. 30 no. 3. 1-16.

Morkhoven, F.P.C.M., Berggren, W.A., Edward, S.A., 1986. Cenozoic cosmopolitan deep-water benthic foraminifera. Pau. Elf-Aquitaine.

Murray, J.W., 1976. A method of determining proximity of marginal seas to an ocean, Marine Geology 22. 103 - 119.

Natsir, S.M., Dewi, K.T., dan Ardhyastuti, S., 2017. Keterkaitan foraminifera dan kedalaman perairan sebelah tenggara Pulau Seram, Maluku, Jurnal Geologi Kelautan vol. 15 no. 2.73 - 80.

Panggabean, H. dan Surono, 2011. Tektono-stratigrafi Bagian Timur Sulawesi, Jurnal Sumber Daya Geologi vol. 21 no. 5. $239-248$.

Prabawa, G., Jambak, M.A., Harnest, B., Irano, T., Ibrahim, I., 2020. Rejuvenating the concept of The Salodik Group Reservoir of The Banggai Basin through Surface Geological Mapping and multi-method analyses, Proceedings of Indonesian Petroleum Association Digital Technical Conference.

Postuma, J.A., 1971. Manual of Planktonic Foraminifera, Elsevier Publishing Company, Amsterdam.

Putri D.D., Mardiana, U., Firmansyah, Y., Pratama, P.Y., dan Dzakirin, D.F., 2018. Sebaran fasies pengendapan restricted platform-lagoon batuan karbonat Kelompok Mentawa di Lapangan "SN" Cekungan Banggai-Sula, Sulawesi Tengah berdasarkan data core, biostratigrafi, dan well log, Padjadjaran Geoscience Journal vol. 2 no.6. 462 - 472.

Simmons, M., 2019, Biostratigraphy in Exploration - Exploration Handbook, Halliburton Landmark, London.

Yoga, P., Dzakirin, D.F., Luqman, Rahadian, R., Helbet, R., Anastasia, S., Waris, B., Junaedi, Wibowo, R., dan Haryanto, S., 2020. Facies analysis using biostratigraphy data and also development controlling factors of Miocene Carbonate Buildups, Central Sulawesi, Proceedings of SPE/IATMI Asia Pacific Oil and gas Conference and Exhibition. 